\title{
JOURNAL.RU
}

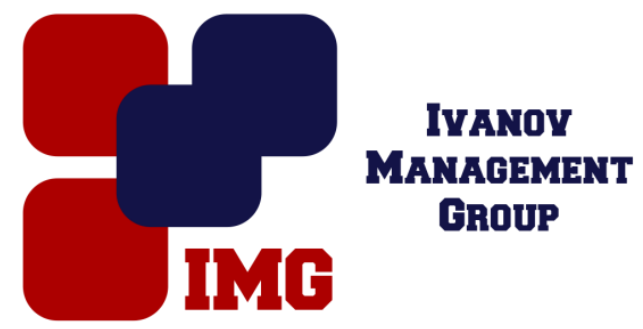

Лебедева А.Н. Набережночелнинский филиал ЧОУ ВО «Казанский инновационный университет им. В.Г. Тимирясова (ИЭУП)» Набережные Челны, Россия

doi: $10.18411 / 1 \mathrm{j}-31-05-2017-50$

idsp 000001:1j-31-05-2017-50

\section{К вопросу о понятии реального и консенсуального договора}

\section{Аннотация}

Статья посвящена анализу правовой природы реальных и консенсуальных договоров.Сделан вывод, что при заключении договора необходимо в каждом конкретном случае определять его правовую природу и в соответствии с этим формулировать его условия и осуществлять действия по его исполнению.

Ключевые слова: реальный договор, консенсуальный договор, непоименованный договор

Проблема реальности и (или) консенсуальности договора является актуальной для судебно-арбитражной практики, анализ которой позволяет сделать вывод о том, что сторонами, а в некоторых случаях и судом, не всегда правильно понимаются нормы действующего законодательства относительно правовой природы этих договоров.

Понятие реальных и (или) консенсуальных договоров в законодательстве не раскрыто. Это понятие традиционно для цивилистики и выведено доктриной гражданского права, что нашло свое отражение в п.1, 2 ст. 433 ГК РФ.

Для заключения некоторых договоров законом может быть предусмотрена необходимость передачи имущества (п. 2 ст. 433 ГК РФ). Это реальные договоры, для заключения которых помимо достижения соглашения по всем существенным условиям необходима еще и передача имущества. Именно с момента передачи имущества такие договоры считаются заключенными. При этом передача имущества может состояться как в момент достижения 
соглашения по всем условиям договора, так может быть и отсрочена во времени. В любом случае передача имущества для таких договоров - это обязательное условие их заключения, окончательная реализация намерений сторон заключить договор, условия которого выражены в их соглашении. Следует отметить, что реальные договоры в гражданском праве встречаются гораздо реже, чем консенсуальные.

В.В. Груздев выделяет следующие типы: договор дарения, не связанный с обещанием дарения; договор ренты; договор безвозмездного пользования, за исключением договора, по которому ссудодатель обязуется передать вещь ссудополучателю; договор перевозки; договор займа; договор финансирования под уступку денежного требования, за исключением договора, по которому финансовый агент обязуется передать клиенту денежные средства в счет денежного требования клиента к третьему лицу; договор банковского вклада; договор хранения, не связанный с обязанностью профессионального хранителя принять вещь на хранение в будущем; договор страхования; договор доверительного управления имуществом.

Перечень выделяемых В.В. Груздевым типов реальных договоров является неполным, поскольку он называет лишь договоры, которые находятся в ч. 2 ГК РФ. Необходимо отметить, что полный перечень реальных договоров дать затруднительно, поскольку условие о реальности может быть предусмотрено помимо ГК РФ и другим законом. В самом Кодексе в качестве реальных договоров можно выделить также соглашение о задатке (ст. 380), договор залога имущества, подлежащего передаче залогодержателю (ст. 341). Дискуссионной является правовая природа соглашения об отступном.

В законодательстве условие о реальности договора формулируется следующими способами:

во-первых, путем указания на необходимость передачи имущества как условие заключения договора. Так, договор займа считается заключенным с момента передачи денег или других вещей (абз. 2 п. 1 ст. 807 ГК РФ), договор страхования вступает в силу в момент уплаты страховой премии или первого ее взноса (п. 1 ст. 957 ГК РФ);

во-вторых, путем указания в договоре, что кредитор «передает», а не «обязуется передать» (последнее свойственно консенсуальным договорам).

Правда, иногда стороны необоснованно считают реальными все договоры о передаче имущества. Так, в постановлении ФАС Волго-Вятского округа указано, что заявитель жалобы ошибочно считает реальным договоры аренды; в 
постановлении ФАС Северо-Западного округа о суд указал на ошибочность взглядов заявителя на реальность правовой природы кредитного договора.

Поскольку виды договоров, для заключения которых необходима передача имущества (реальные договоры), должны быть предусмотрены законом (п. 2 ст. 433 ГК РФ), то получается, что их перечень является исчерпывающим. Более того, условие о реальности договора является императивным, поэтому стороны не могут заключить реальный по правовой природе договор в форме консенсуального. Так, договор займа ни при каких условиях не может быть консенсуальным. В противном случае условия договоров, позволяющие считать консенсуальным реальный по природе договор, должны признаваться недействительными, а такой договор в случае непередачи имущества незаключенным.

Поскольку перечень реальных договоров является исчерпывающим, то стороны лишены права придавать статус реальной сделки и так называемым непоименованным договорам. Непоименованные договоры, возможность заключения которых предусмотрена п.2 ст.421 ГК РФ, всегда являются консенсуальными. В случае, если такой договор содержит условие о том, что он считается заключенным с момента передачи имущества, такое условие считается недействительным, а непоименованный договор как консенсуальный по природе заключенным.

Сложнее обстоит дело со смешанными договорами. В отношении них в правовой науке высказывается мнение об учете в соответствующих частях правил о договорах, элементы которых содержатся в смешанном договоре, их равнозначности или соподчиненности. Поэтому в каждом конкретном случае в зависимости от доминирования в смешанном договоре элементов того или иного договора должен решаться вопрос о его правовой природе.

Стороны не вправе своим волеизъявлением изменить и консенсуальную природу договора. В практике часто встречаются случаи, когда заключаются, например, договоры аренды, купли-продажи недвижимости и т.д., в которых указывается, что они вступают в силу с момента передачи имущества по акту приема-передачи. Такие договоры не могут быть признаны незаключенными в случае непередачи имущества, поскольку стороны не вправе своим волеизъявлением придать консенсуальной природе договора реальный характер. В данном случае такие условия в договоре должны признаваться недействительными как противоречащие п. 2 ст. 433 ГК РФ, а договоры заключенными. 
Необходимо учитывать, что некоторые договоры в сформулированы альтернативно, т.е. Кодекс допускает и консенсуальный, и реальный характер таких договоров, ставя решение этого вопроса в зависимость от волеизъявления сторон. Так сформулированы договоры залога, дарения, безвозмездного пользования (ссуды), финансирования под уступку денежного требования, по которым одна сторона «передает» (реальный) или «обязуется передать» (консенсуальный) другой стороне определенное имущество. Применительно к данным видам договоров в каждом конкретном случае сторонам необходимо четко формулировать его условия. Из текста договора должна явствовать воля на заключение конкретного типа договора (реального или консенсуального). Если такого условия в договоре не окажется, то правовую природу договора определять следует, применяя толкование его условий в соответствии со ст. 431 ГК РФ.

Таким образом, при заключении договора необходимо в каждом конкретном случае определять его правовую природу и в соответствии с этим формулировать его условия и осуществлять действия по его исполнению.

$* * *$

1. Гражданский кодекс Российской Федерации. Часть вторая / Федеральный закон от 26 января 1996 г. № 14-Ф3 // Собрание законодательства РФ. -1996. -№ 5. -Ст. 410.

2. Гражданский кодекс Российской Федерации. Часть первая / Федеральный закон РФ от 30 ноября 1994 г. // Собрание законодательства РФ. -1994. -№ 32. - Ст.3301.

3. Груздев В.В. Реальные договоры в российском гражданском праве // Право и экономика. -2001. -№ 1. - С. 33-35.

4. Ковалева Н.В. Деление сделок на консесуальные и реальные в цивилистике // Вестник Костромского государственного технологического университета. -2008. - № 19. -С. 48-51.

5. Постановление Федерального арбитражного суда Волго-Вятского округа от 10 октября 2011 г. № А29-1329/11-2э «Договор аренды является консенсуальным и считается заключенным с момента достижения сторонами соглашения по его существенным условиям. Момент вступления договора в силу не связывается с передачей арендованного имущества арендатору» // Режим доступа: http://base.garant.ru/8542295/

6. Постановление Федерального арбитражного суда Северо-Западного округа от 30 октября 2010 г. № А05-2327/10-5/22 «По иску Банка о взыскании солидарно с ОАО и предпринимателя-поручителя задолженности по кредитному договору, процентов за пользование кредитом, пени за несвоевременный возврат кредита, пени за несвоевременную уплату процентов и расходов по госпошлине»// Режим доступа: http://base.garant.ru/7966781/

7. Токарева К.Г. О консенсуальном характере договора ренты // Альманах современной науки и образования. - 2009. - №7 (26). Часть 2. - С.146-147.

8. Токарева К.Г. О проблемах правовой конструкции договора ренты // Современное право. -2006 . -№ 10. - С. 28-31. 